\title{
First Serological and Molecular Detection of Leptospira interrogans serovar canicola Bacteria in Dogs in Some Iraqi Governorates
}

\author{
Hams Hussien Hashim Handool Alfattli ${ }^{1} \quad$ Saba Abood Ali Al-Mohamed ${ }^{2}$ \\ hams.hashim@qu.edu.iq ${ }^{1}$ saba.ali@qu.edu.iq ${ }^{2}$ \\ College of Pharmacology / Al-Qadisiyah University 1, 2
}

\begin{abstract}
The aim of present study was to serodetect of canine leptospirosis by using of indirect ELISA, and identification of Leptospira interrogans serovar canicola in serpositive dogs by application of PCR technique. For this purpose, 218 dogs from urban and rural regions related to three governorates were submitted for blood samples collection. The total results were revealed on $37 / 218$ (16.97\%) and 5/37 (13.51\%) infected positive dogs by an indirect ELISA and PCR techniques, respectively. According to subjected study's governorates, the positive results of indirect ELISA in Baghdad, Al-Qadisiyah and Dhi-Qar were 23/108 (21.3\%), 10/79 (12.66\%), and 4/31 (12.9\%), respectively; while by PCR assay, the positive results $\{5 / 23(21.74 \%)\}$ had been detected in Baghdad only. Also, the relationship of positive dogs with some epidemiological risk factors has been discussed in this study. In association to inhabitant type, the rural and urban regions, respectively, were having $16 / 82(19.51 \%)$ and $21 / 136(15.44 \%)$ positive dogs by indirect ELISA; whereas, they have 4/16 (25\%) and 1/21 (4.76\%) positive dogs by PCR, respectively. In regarding to sex factor, the positive infected males and females, respectively, were amounted $13 / 67(19.4 \%)$ and $24 / 151(15.89 \%)$ by indirect ELISA; and $2 / 13(15.38 \%)$ and $3 / 24(12.5 \%)$ by PCR. In relation to age factor, $>2$ years and $\leq 2$ years groups have taken 36/149 (24.16\%) and 1/69 (1.45\%) positive dogs by indirect ELISA and $5 / 36$ (13.89\%) positive dogs for $>2$ years group, only, by PCR assay.

Statistically, the positive results were reported significant differences at level of $\mathrm{P} \leq 0.05$ between the study's regions and between the groups related to each epidemiological risk factor.
\end{abstract}

Keywords: Leptospira interrogans, Canicola, dogs, Serological, Molecular, Iraq 
العـــــــد الثامن والعشرون

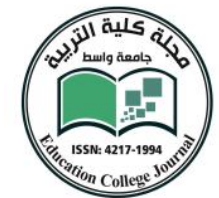

Leptospira interrogans serovar الكثف المصلي والجزيئي الاول لبكتيريا canicola

صبا عبود علي المحمد ‘

همس حسين هاشم هندول الفتلي'

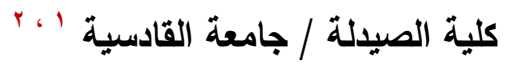

الخلاصة

هدفت الدراسة الحالية الى التحري المصلي لداء الللييتوسباير الكلابية باستعمال indirect-ELISA، وتأكيد

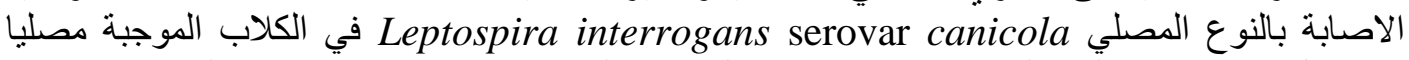

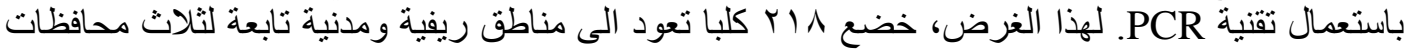

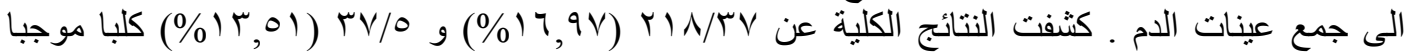

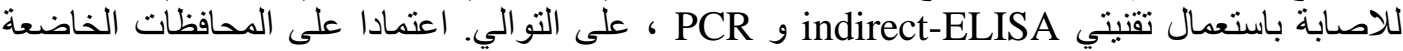

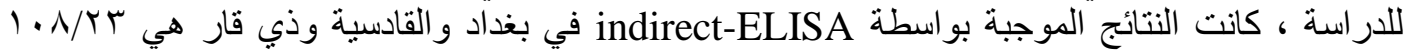

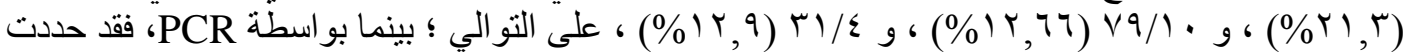

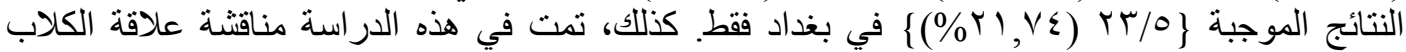

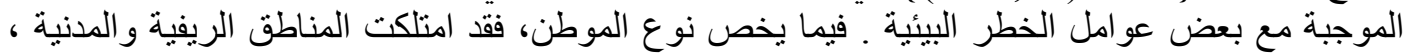

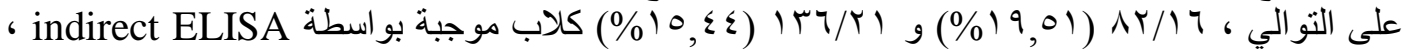

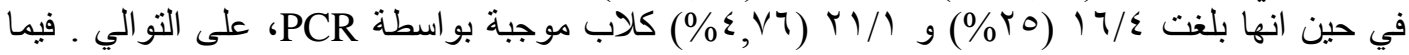

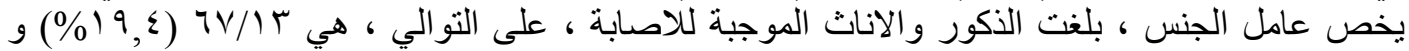

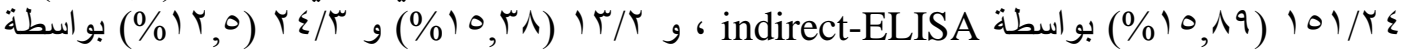

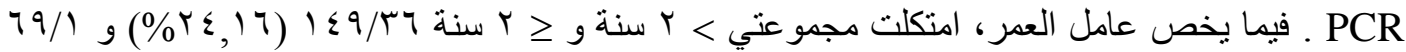

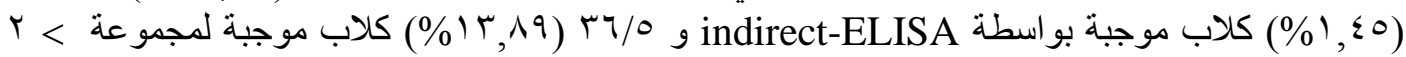
سنة ، فقط ، بواسطة اختبار PCR

احصائيا ، سجلت النتائج الموجبة اختلافات معنوية عند مستوى P ب بين مناطق الدر اسة وبين المجاميع التي ترتبط بكل عامل خطر وبائي .

الكلمات المفتاحية : Canicola ، Leptospira interrogans ، كلاب ، مصلي ، جزيئي ، العراق 


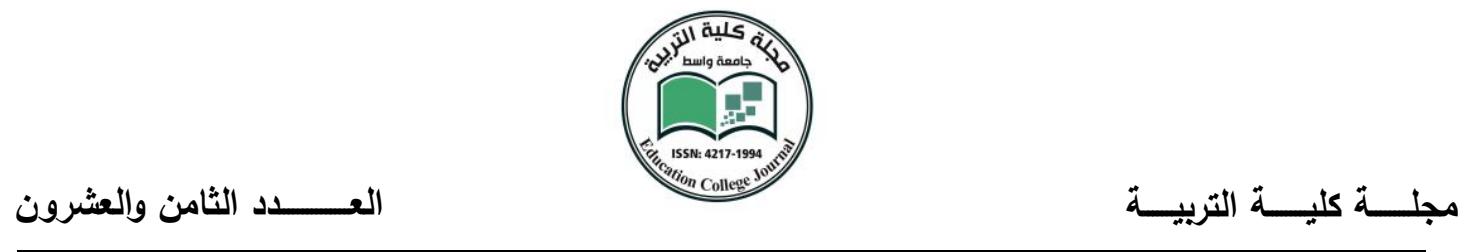

\section{Introduction}

Leptospira is a gram negative, aerobic spirochaetal bacterium that infecting many mammals to cause an acute infectious illness for humans and leading to a potential economic losses and public health issues in domestic and wild animals (1). Although, rats consider the main reservoir and source of human infections, dogs may play a role as pathogen reservoir in the leptospirosis cycle (2). There is general consensus that dogs more frequent exposure to diseases risk and they can act sentinels for environmental contamination and as an indicators for human exposure risk (3). All cases of canine leptospirosis are caused by infection with Leptospira interogans that comprised on 23 serogroups and more than 250 pathogenic serovars distributed worldwide (4). The specific serovars are maintained, naturally, by several sub-clinical infected domestic and wild reservoirs that act as sources of exposure and illness for other incidental hosts (5). The most commonly incriminated serovars in canine leptospirosis are including Canicola, Icterohaemorrhagiae, Pomona, Bratislava, and Grippotyphosa (6).

Although, the diagnosis of leptospirosis is based, mainly, on culturing of blood, urine, and cerebrospinal fluid on specific media, most laboratories don't attempt to isolate of Leptospira because of their fragile nature, the cost and complexity of the isolation media, and prolonging of incubation period (7). Hence, the serological tests play an important role in the recognition of leptoepiral infection with varying degrees in serogroup and serovar specificity (8). However, two serologically diagnostic tests demonstrated a high capability in detection of infections in veterinary field including microscopic agglutination test (MAT) and enzyme-linked immunosorbent assay (ELISA) (9). ELISA is intended to use in identification of specific IgM or IgG antibodies against sugar Leptospira antigens with high specificity, sensitivity, and objectivity by using serum samples. The only disadvantage of ELISA is that a single genus-specific antigen and it does not give an indication for infecting serovar $(\mathbf{1 0}, \mathbf{1 1})$. Nonetheless, amplification of leptospiral DNA by PCR technique is required to demonstrate an infective serovar with a high sensitivity and specificity, and it can detect the pathogen from blood or urine of infected animal (12). 
To our knowledge, this is the first study carried out in Iraq for serological detection of canine leptospirosis among stray dogs in some Iraqi governorates by using an indirect-ELISA and confirmation of Leptospira interogans serovar canicola in seropositive dogs by using of PCR technique. Also, some epidemiological risk factors and their associations with positive dogs were discussed in this study.

\section{Materials and Methods}

\section{Study's areas and samples collection}

From several rural and urban regions within three Iraqi governorates (Baghdad, AlQadisiyah, and Dhi-Qar) and during the period from August 2015 to July 2016, a totally of 218 stray dogs from both sexes, selected randomly, were submitted for this study. From each dog, about $6 \mathrm{ml}$ of venous blood samples was drained by using a disposable syringe. Four $\mathrm{ml}$ of each blood sample was inserted into plain tube, allowed to clot, and then centrifuged for 10 minutes at $3000 \mathrm{rpm}$ for serum collection. The serum samples were pipetted into $1 \mathrm{ml}$ appendorff - microtubes and stored at $-20^{\circ} \mathrm{C}$ until tested by ELISA (13). While, the rest two $\mathrm{ml}$ of blood sample was saved into an EDTA tube for DNA extraction.

\section{Indirect ELISA}

The serum samples of all study's dogs were tested by using a monoclonal-mediated ELISA to detect the specific IgG-antibodies against canine leptospirosis (Eurovet Veterinaria-Spain). According to manufacturer's instructions of ELISA kit (Catalog No: D1013-AB01), the test protocol was applied, and the results were read at a wave length of $450 \mathrm{~nm}$ by using a microplate photometer ELISA-reader (BioTek-USA). Also, the validation and interpretation of test results have been discussed in depending on optical densities of these results as detailed in (Table 1). 


\begin{tabular}{|c|c|}
\hline العـــــــدـد الثامن والعشرون & كليــــة التربيــــة \\
\hline \multicolumn{2}{|c|}{ Table (1): Validation and interpretation of test results } \\
\hline \multicolumn{2}{|c|}{ Validation } \\
\hline Negative Control & $\mathrm{OD}<0.350$ \\
\hline Positive Control & $\mathrm{OD}>0.700$ \\
\hline \multicolumn{2}{|r|}{ Interpretation } \\
\hline Negative Samples & $\mathrm{OD}_{\text {Sample }}<$ mean OD $\mathrm{Negative} \mathrm{Control}+0.150$ \\
\hline Positive Samples & $\mathrm{OD}_{\text {Sample }}>$ mean OD Negative Control +0.250 \\
\hline
\end{tabular}

\section{PCR}

DNA Extraction: According to manufacturer's instructions, $(200 \mu \mathrm{L})$ of EDTA blood samples were employed for Leptospira DNA extraction through using of QIAamp DNA blood mini kit (Qiagen-Germany). The eluted DNA was quantified, and the purity was checked by using of spectrophotometer (BioTek-USA).

DNA Amplification: The amplification was carried out by using two pairs of primers targeting to confirm of Leptospira interrogans species and Canicola serovar, respectively. These primers were amplifying the DNA products of $547 \mathrm{bp}$ and $793 \mathrm{bp}$ and corresponded to hypothetical open reading frame upstream of conserved ribosomal proteins (GenBank accession number AY622662), and included: rr-outer-F (5'-CTCAGAACTAACGCTGGCGGCGCG-3') and rrs-outer$\mathrm{R}$ (5'-GG TTCGTTACTGAGGGTTAAAACCCCC-3') rrs - inner-F (5'CTTGATAGAAC CACTGGTGGTGCC-3') and rrs-inner-R (5'CTGGATCGGTTCCATCGCTCAG-3') $(\mathbf{1 4}, \mathbf{1 5})$. The amplification was processed by using of thermal cycler (PTC-100/MJ-BIO RAD / USA) and initiated with one cycle $\left(94^{\circ} \mathrm{C} / 5\right.$ minutes), followed by 45 cycles $\left(94^{\circ} \mathrm{C} / 1\right.$ minute), $\left(56^{\circ} \mathrm{C} / 1\right.$ minute), $\left(72^{\circ} \mathrm{C} / 90\right.$ seconds), and with final elongation one cycle $\left(72^{\circ} \mathrm{C} / 10\right.$ minutes $)$. The PCR reaction was carried out by using of a thermal cycler (ThermoFisher-USA). $L$. interrogans serovar canicola genomic DNA was used as a positive control and the DNAase-free water as a negative control in all PCR runs. The amplified products were separated on $2 \%$ agarose-gel stained (Qiagen-Germany). The amplified DNA products were stained with ethidium bromide (Qiagen-Germany) and visualized under Ultraviolet. 


\section{Data Analysis}

All data were ranged and tabled by using a computerized Microsoft Office Excel (2010) program, while, the results were analysed by using of Chi-Square $\left(x^{2}\right)$ test of IBM/SPSS computerized program $(v 23)$ at a level of $P \leq 0.05$ (16). The statistical differences were estimated between seroprevalence of canine leptosposis and the results of PCR. Also, some epidemiological risk factors (inhabitant area, sex, and age) were discussed in this study.

\section{Results}

In (Table 2): The total seroprevalence results of 218 dogs, tested by using of an indirect ELISA revealed on 37 (16.97\%) dogs were seropositives.

Table (2): Seroprevalence of specific IgG-antibodies against canine leptospirosis

\begin{tabular}{|c|c|c|}
\hline Total No. & Seropositives & Seronegative \\
\hline $\mathbf{2 1 8}$ & $\mathbf{3 7}(16.97 \%)$ & $\mathbf{1 8 1}(83.03 \%)$ \\
\hline
\end{tabular}

In (Table 3): The totally 37 seropositive dogs by an indirect ELISA were tested by using of PCR technique, and the results showed that $5(13.51 \%)$ of these dogs were positive, molecularly, for Leptospira interrogans serovar canicola.

Table (3): Results of PCR technique on seropositive dogs

\begin{tabular}{|c|c|c|}
\hline Total No. & Positives & Negatives \\
\hline $\mathbf{3 7}$ & $\mathbf{5}(13.51 \%)^{\mathrm{B}}$ & $\mathbf{3 2}(86.49 \%)^{\mathrm{A}}$ \\
\hline
\end{tabular}

Variation in large letters, horizontally, referred to significant differences at level of $\mathrm{P} \leq 0.05$

In (Fig.1) that explain the positive samples in agarose-gel electrophoresis of PCR products. Whereas, Lane M referred to DNA marker (100-1500bp), Lane (1-5) was 
العـــــــد الثامن والعشرون

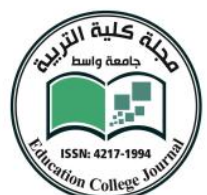

represented the positive samples at $547 \mathrm{bp}$ and $793 \mathrm{bp}$ PCR product size at $2 \%$ agarose, 100 Volt and 80 Am for 1 hour.

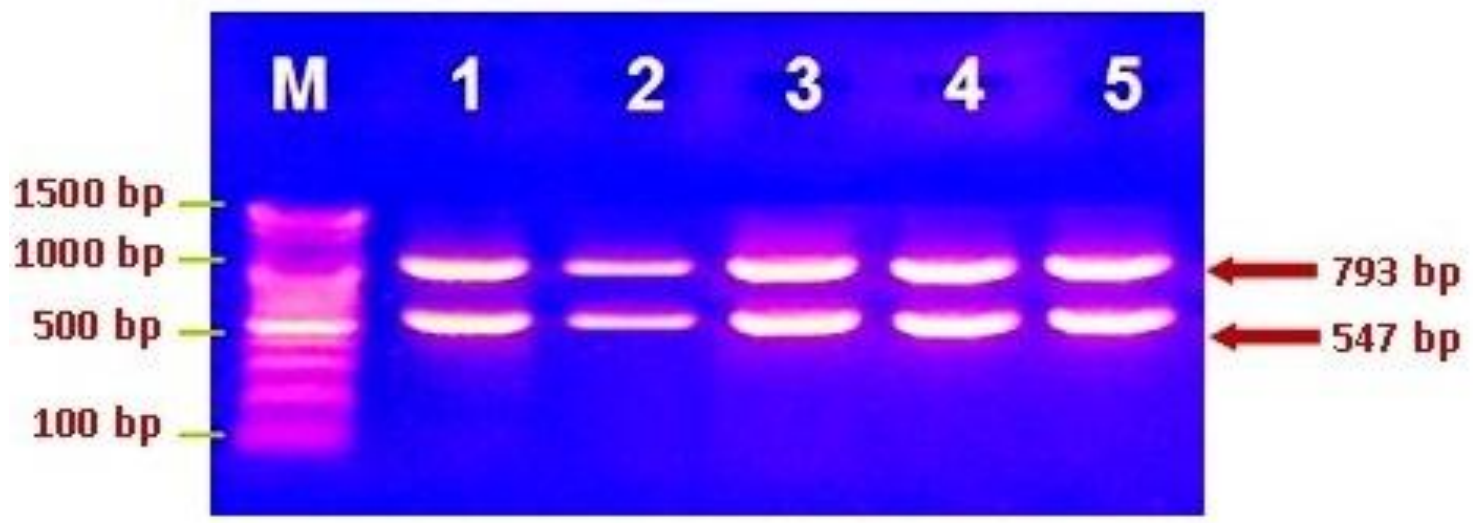

Figure (1): Agarose-gel electrophoresis for PCR products of L. interrogans serovar canicola positive isolates

In (Table 4): According to governorate, the positive results that detected by indirect ELISA in a totally 108 dogs in Baghdad, 79 dogs in Al-Qadisiyah, and 31 dogs in Dhi-Qar governorates were 23 (21.3\%), 10 (12.66\%), and 4 (12.9\%), while by PCR technique, the positive results were $5(21.74 \%)$ that showed in Baghdad governorate, only. By both assays, Baghdad governorate were reported a significant increasing in their positive results more than in Al-Qadisiyah and DhiQar governorates $(\mathrm{P} \leq 0.05)$.

Table (4): Positive results of ELISA and PCR assay, according to study's governorate

\begin{tabular}{|c|c|c|c|c|}
\hline \multicolumn{2}{|c|}{ Governorate } & No. & Seropositives & PCR positives \\
\hline $\mathbf{1}$ & Baghdad & $\mathbf{1 0 8}$ & $\mathbf{2 3}(21.3 \%)^{\mathrm{a}}$ & $\mathbf{5}(21.74 \%)^{\mathrm{a}}$ \\
\hline $\mathbf{2}$ & Al-Qadisiyah & $\mathbf{7 9}$ & $\mathbf{1 0}(12.66 \%)^{\mathrm{b}}$ & $\mathbf{0}(0 \%)^{\mathrm{b}}$ \\
\hline $\mathbf{3}$ & Dhi-Qar & $\mathbf{3 1}$ & $\mathbf{4}(12.9 \%)^{\mathrm{b}}$ & $\mathbf{0}(0 \%)^{\mathrm{b}}$ \\
\hline & Total & $\mathbf{2 1 8}$ & $\mathbf{3 7}(\mathbf{6 . 8 2} \%)$ & $\mathbf{5}(\mathbf{1 3 . 5 1} \%)$ \\
\hline
\end{tabular}

Variation in small letters, vertically, referred to significant differences at level of $\mathrm{P} \leq 0.05$ 
In (Table 5): The associations of positive samples by indirect ELISA and PCR technique with some epidemiological risk factors \{inhabitant type (Fig. 1), sex (Fig. 2), and age (Fig. 3) \} were detailed as follow:

Table (5): Association of positive dogs by ELISA and PCR to epidemiological risk factors

\begin{tabular}{|c|c|c|c|c|}
\hline \multicolumn{2}{|r|}{ Risk factors } & No. & Seropositives & PCR positives \\
\hline 1 & $\begin{array}{c}\text { Inhabitant Type } \\
\text { Rural regions } \\
\text { Urban regions }\end{array}$ & $\begin{array}{c}82 \\
136\end{array}$ & $\begin{array}{l}\mathbf{1 6}(19.51 \%)^{\mathrm{a}} \\
\mathbf{2 1}(15.44 \%)^{\mathrm{b}}\end{array}$ & $\begin{array}{c}\mathbf{4}(25 \%)^{\mathrm{a}} \\
\mathbf{1}(4.76 \%)^{\mathrm{b}}\end{array}$ \\
\hline 2 & $\begin{array}{c}\text { Sex } \\
\text { Male } \\
\text { Female } \\
\end{array}$ & $\begin{array}{c}67 \\
151\end{array}$ & $\begin{array}{c}\mathbf{1 3}(19.4 \%)^{\mathrm{a}} \\
\mathbf{2 4}(15.89 \%)^{\mathrm{b}}\end{array}$ & $\begin{array}{c}\mathbf{2}(15.38 \%)^{\mathrm{b}} \\
\mathbf{3}(12.5 \%)^{\mathrm{a}}\end{array}$ \\
\hline 3 & $\begin{aligned} & \text { Age } \\
> & 2 \text { Years } \\
\leq & 2 \text { Years }\end{aligned}$ & $\begin{array}{c}149 \\
69\end{array}$ & $\begin{array}{c}\mathbf{3 6}(24.16 \%)^{\mathrm{a}} \\
\mathbf{1}(1.45 \%)^{\mathrm{b}}\end{array}$ & $\begin{array}{c}5(13.89 \%)^{\mathrm{a}} \\
\mathbf{0}(0 \%)^{\mathrm{b}}\end{array}$ \\
\hline
\end{tabular}

Variation in small letters, vertically, within each factor referred to significant differences at level of $\mathrm{P} \leq 0.05$

In (Fig.2) dealt with an inhabitant type risk factor, the animals of study were involved 82 dogs from rural regions and 136 ones from urban regions. The seropositive results by indirect ELISA were 16/82 (19.51\%) and 21/136 (15.44\%), respectively; while by PCR test, the positive results were 4/16 (25\%) and 1/21 $(4.76 \%)$, respectively. By both tests, the significant differences were reported between rural and urban regions, males and females, and $>2$ years and $\leq 2$ years at level of $(\mathrm{P} \leq 0.05)$. 

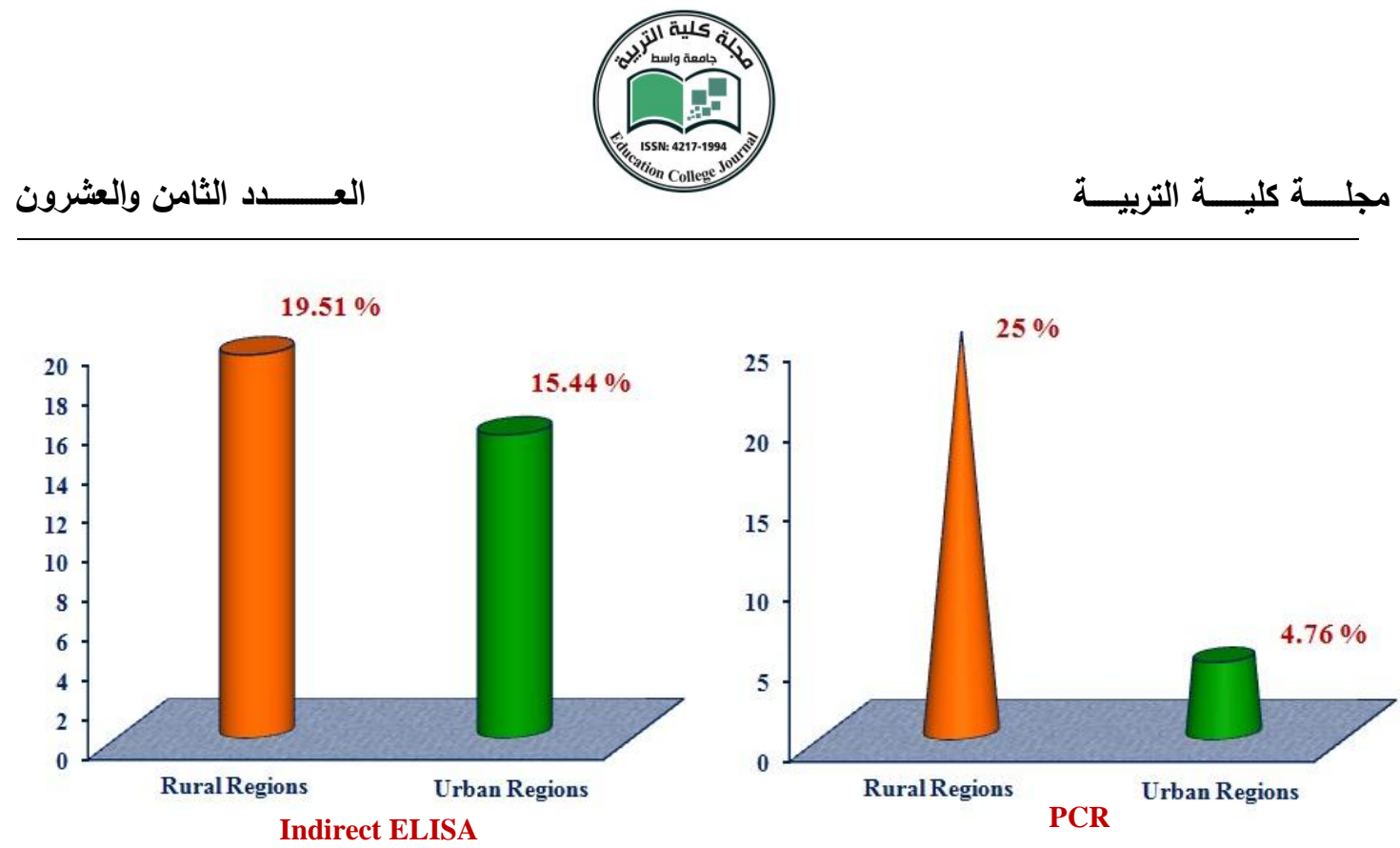

Figure (2): An association of positive dogs by indirect ELISA and PCR

to inhabitant type risk factor

In (Fig.2) dealt with the sex risk factor, the study comprised from 67 males and 151 females, and the seropositive dogs by indirect ELISA were 13/67 (19.4\%) and 24/151 (15.89\%), respectively; whereas by PCR technique, $2 / 13$ (15.38\%) and 3/24 $(12.5 \%)$ positive dogs were detected in males and females, respectively.
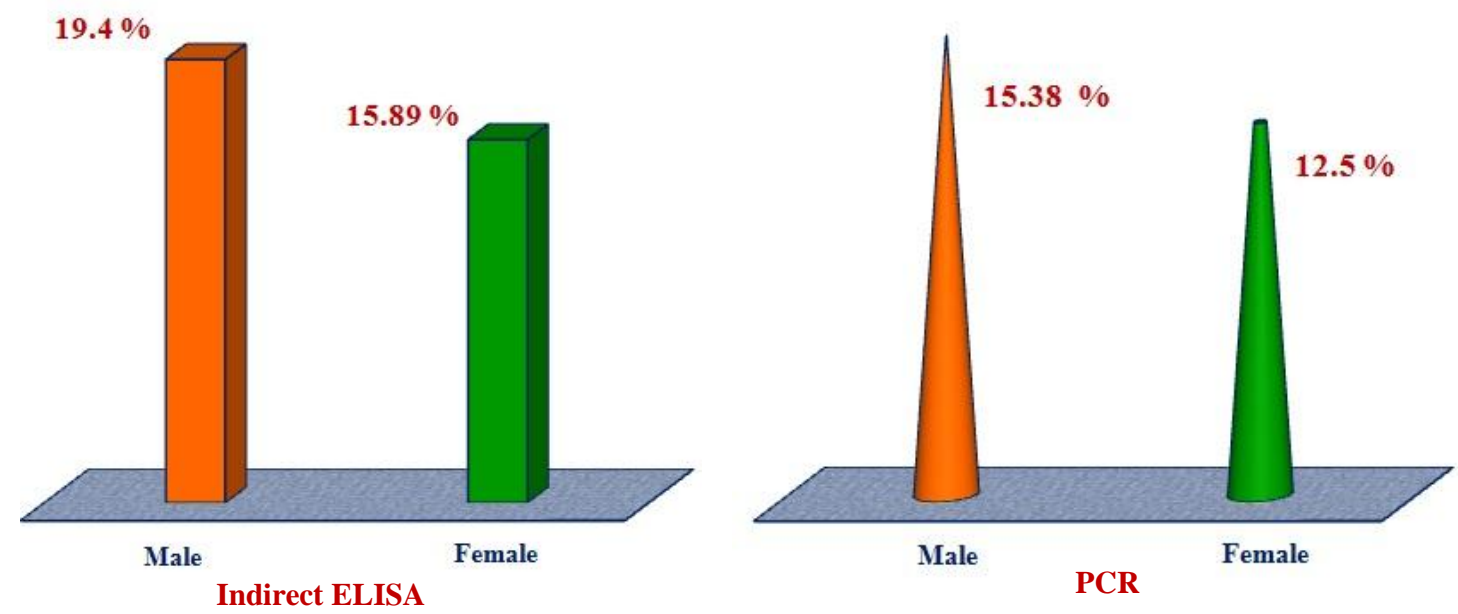

Figure (2): An association of positive dogs by indirect ELISA and PCR to sex risk factor 
In (Fig.3) dealt with the age factor, the study's dogs were divided into two age groups, $>2$ years $(149 \mathrm{dogs})$ and $\leq(69 \mathrm{dogs})$, and the positive results by indirect ELISA were $36 / 149(24.16 \%)$ and $1 / 69$ (1.45\%), respectively; while by PCR technique, $5 / 36(13.89 \%)$ was the positive result that reported in $>2$ years age group, only.
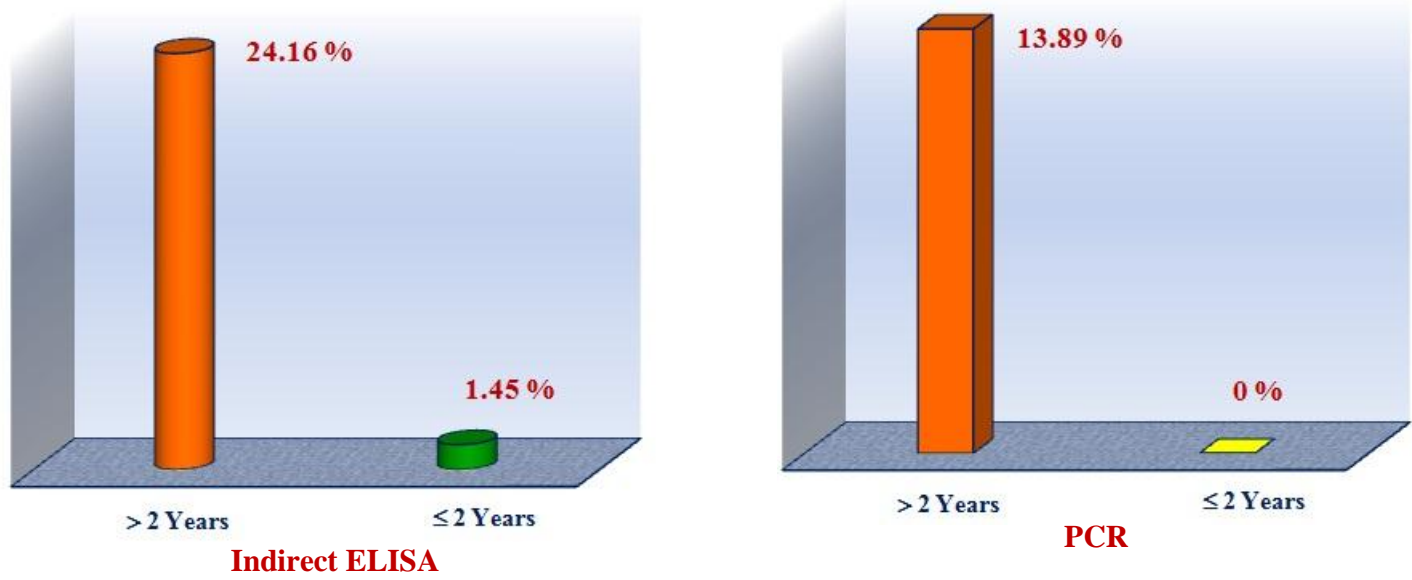

Figure (3): An association of positive dogs by indirect ELISA and PCR to age risk factor

\section{Discussion}

In Iraq, this study was performed, firstly, for detection of canine leptospirosis that caused by Leptospira interrogans serovar canicola. The indirect ELISA and PCR technique have been established that 37/218 (16.97\%) and 5/37 (13.51\%) of examined dogs were positives, respectively. Nonetheless, this study showed that the positive results of PCR test were less than those reported by indirect-ELISA, and this could because of low sensitivity of PCR in compared to ELISA test (17), or might be attributable to substances persisted in clotted whole blood samples such as the hemoglobin derivatives, creatinine and urea that could have inhibited for DNA amplification with the leptospiral primers (18). However, several studies demonstrated the importance of PCR test as a complementary test in confirmation of leptospirosis due to the high specificity of it if compared with serological tests and blood culture due to an absence of specific antibodies in early stage of 


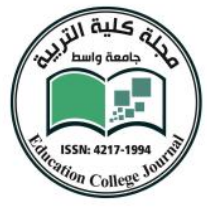

infection and the fastidious nature of leptospires during cultivation on specific agars $(\mathbf{1 7}, \mathbf{1 9}, \mathbf{2 0})$. In according to regions of samples collection, the positive results that reported in Baghdad governorate $\{23 / 108(21.3 \%)$ and 5/23 (21.74\%) $\}$ were higher than those reported in Al-Qadisiyah $\{10 / 79(12.66 \%)$ and $0 / 10(0 \%)\}$, and Dhi-Qar $\{4 / 31(12.9 \%)$ and $0 / 4(0 \%)\}$ by both indirect ELISA and PCR, respectively. Worldwide, the seroprevalence of canine Leptospira spp. was varied widely between countries, in Iran (31\%) (21), Turkey (43.96\%) (22), Egypt (11.3\%) (23), Japan (3.9-27\%) (5), USA (24.9\%) (24), Brazil (7.1-32.2\%) (25). As reported by (26), about 10 different canine serovars have been associated with clinical disease, and the most frequently described serovars included Canicola, Icterohaemorrhagiae, Pomona, Bratislava, and Grippotyphosa. Recently, the serological evidence demonstrated an occurrence of unexpected changes in predominant serovars implicated in canine leptospirosis, and this change has been attributed to widespread use of bivalent Leptospira vaccines as well as increased contact between dogs and other animals, especially wild life reservoirs in expanding suburban environments $(\mathbf{2 7}, \mathbf{2 8})$. In developing countries, it's thought to that the frequent variation in climatic conditions, especially; high temperature and rainfall during specific periods of the year could be play an effective role in the elevated rates of canine leptospirosis cases (29).

In regarding to the inhabitant type of risk factor, the rural regions reported by indirect ELISA, a significant seropositive prevalence 16/82 (19.51\%) higher than urban regions 21/36 (15.44\%); and by PCR, 4/16 (25\%) positive dogs in rurals and $1 / 21(4.76 \%)$ positive dogs in urbans. However, the significant increasing of positives in rurals other than urbans could be attributed to many factors as lack of basic sanitation, poor housing conditions, and limited health education that could be represented great risks for human infections, particularly, in rural areas (30). Many studies reported that herding, hounds, stray, and mixed-breed dogs were at highly risk if compared to companion dogs, which presumably, because of increasing the outdoor exposure for contaminated environments (31). Stray dogs that roaming, freely, in cities could be represented an important source in the transmission of infection because of their potential contacts with the infected canines or rodents (32). Also, the widespread using of bivalent vaccines specific, serovarly, for only Canicola and Icterohaemorrhagiae has been resulted in decreasing prevalence of these serovars, and increasing awareness for infection 
with Pomona, Bratislava, and Grippotyphosa serovars particularly in last past 20 years (33). The predominance of canine leptospirosis that associated with these latter serovars was, likely, concerned with an increasing exposure of dogs to wild reservoir hosts in rural or suburban regions (34). In addition, several epidemiological studies demonstrated that the rural areas prone to have a higher risk for infections because of these environments are tend to have larger rates of reservoirs that in contact with the dogs $(35,36)$.

In related to sex risk factor, the current study showed that in 13/ $67(19.4 \%)$ and $2 / 13(15.38 \%)$ of males were positives by indirect ELISA and PCR, while, the positive infections rate that reported in females by both assays were 24/151 (15.89\%) and 3/24 (12.5\%), respectively. Also, the results of age factor were reported that the dogs with $>2$ years of age have an elevated positive infection rates by indirect ELISA 36/149 (24.16\%) and PCR 5/36 (13.89\%); whereas in $\leq 2$ years group, only $1 / 69(1.45 \%)$ positive dogs have been detected by indirect ELISA. Worldwide, the associations of sex and age factors with positive canine leptospirosis were controversial (25). Nonetheless, (37) showed the possibility of proportions infected dogs, at any age or sex categories, to be changed over time, and the data that used to identify the potential changes of risk factors could be at different points in time. However, (38) showed that male dogs were at significantly higher risk of leptospirosis than females dogs. In addition, dogs in age groups of 410 years of age at a significant greater risk than younger dogs. As reported by (21, 39, 40), Male dogs were more likely to develop leptospirosis than females; probably, due to their natural straying behavior, hormonal influences, increasing their overexposure to environment during socialization process or to temporal gap of immunity. The hypothesis of increasing infection with age might because of reduction the risk that caused by the less outdoor activity, or due to the better immunologic protection as a result of maternally acquired immunity $(37,41)$.

In conclusion, the results of this study were elicited the high seroprevalence of canine leptospiral infections among the stray dogs of rural and urban tested governorates, with efficacy of indirect-ELISA and PCR techniques in detection of specific antibodies and genes of L. interrogans serovar canicola. Nonetheless, the further investigations should be continued on canine leptospirosis in Iraq to detect the endemic serotypes of Leptospira organisms. 


\section{References}

1. Smith, FW. (2015). Blackwell's five-minute Veterinary consult: canine and feline. John Wiley and Sons, 40, 1091-1101.

2. Rojas P., Monahan AM., Schuller S., Miller IS., Markey BK., and Nally, JE. (2010). Detection and quantification of leptospires in urine of dogs: a maintenance host for the zoonotic disease leptospirosis. European journal of clinical microbiology and infectious diseases, 29(10), 1305-1309.

3. Mani I., and Maguire, JH. (2009). Small animal zoonoses and immuncompromised pet owners. Topics in companion animal medicine, 24(4), 164-174.

4. de los Angeles Valverde M., Goris MG., González V., Anchia ME., Diaz P., Ahmed AA., and Hartskeerl, RA. (2016). New serovars of Leptospira isolated from patients in Costa Rica: implications for public health. Epidemiology, clinical aspects and diagnosis, 62(9), 1263-71.

5. Iwamoto E., Yuko WA., Mizuno, T and Okuda, M. (2009). Nationwide survey of Leptospira antibodies in dogs in Japan: results from microscopic agglutination test and enzyme-linked immunosorbent assay. Journal of Veterinary Medical Science, 71(9), 1191-1199.

6. Adler B., and de la Peña Moctezuma, A. (2010). Leptospira and leptospirosis. Veterinary microbiology, 140(3), 287-296.

7. Musso D., and La Scola, B. (2013). Laboratory diagnosis of leptospirosis: a challenge. Journal of Microbiology, Immunology and Infection, 46(4), 245-252.

8. Palaniappan RU., Ramanujam S., and Chang, YF. (2007). Leptospirosis: pathogenesis, immunity, and diagnosis. Current opinion in infectious diseases, 20(3), 284-292.

9. Mamak N., Ozkanlar Y., Kazim-Borku M., and Yilmaz-Imren, H. (2014). Detection of antibodies against Leptospira spp. and Listeria monocytogenes, and intestinal parasite eggs in kangal dogs. Revista Científica, 24(1), 18-23.

10. Safiulah SA., Saleh AA., and Munwar, S. (2009). Laboratory methods for diagnosing leptospirosis: a review. Bangladesh Journal of Medical Microbiology, 3(1), 39-43.

11. Schreier S., Doungchawee G., Chadsuthi S., Triampo D., and Triampo, W. (2013). Leptospirosis: current situation and trends of specific laboratory tests. Expert review of clinical immunology, 9(3), 263-280.

12. Harkin KR., Roshto YM., Sullivan JT., Purvis TJ., and Chengappa, MM. (2003). Comparison of polymerase chain reaction assay, bacteriologic culture, and serologic testing in assessment of prevalence of urinary shedding of leptospires in dogs. Journal of the American Veterinary Medical Association, 222(9), 1230-1233. 


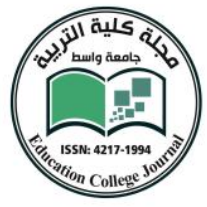

13. Klaasen HL., Molkenboer MJ., Vrijenhoek MP., and Kaashoek, MJ. (2003). Duration of immunity in dogs vaccinated against leptospirosis with a bivalent inactivated vaccine. Veterinary microbiology, 95(1), 121-132.

14. Bandara KK., Weerasekera M., Gunasekara CP., Ranasinghe N., Marasinghe C., and Fernando, N. (2015). Molecular characterisation and disease severity of leptospirosis in Sri Lanka. Memórias do Instituto Oswaldo Cruz, 110(4), 485-491.

15. Reitstetter, RE. (2006). Development of species-specific PCR primer sets for the detection of Leptospira. Federation of European Microbiological Societies, 264 (1), 31-39

16. Petrie A, and Watson, P. (2006). Statistics for Veterinary and Animal Science, Second Edition. Ames: Blackwell Publishing, Pp: 312.

17. de Abreu Fonseca C., Teixeira de Freitas VL., Da Silva MV., Shikanai-Yasuda, MA. (2006). Polymerase chain reaction in comparison with serological tests for early diagnosis of human leptospirosis. Tropical Medicine \& International Health, 11(11), 1699-1707.

18. Rådström P., Knutsson R., Wolffs P., Lövenklev M., and Löfström, C. (2004). PrePCR processing. Molecular biotechnology, 26(2), 133-146.

19. Izurieta R., Galwankar S., and Clem, A. (2008). Leptospirosis: The" mysterious" mimic. Journal of emergencies, trauma, and shock, 1(1), 21.

20. Klaasen HL., Van der Veen M., Molkenboer MJ., and Sutton, D. (2013). A novel tetravalent Leptospira bacterin protects against infection and shedding following challenge in dogs. The Veterinary Record, 172(7), 181.

21. Rad MA., Zeinali A., Vand YJ., Tabatabayi AH., and Bokaie, S. (2004). Seroprevalence and bacteriological study of canine leptospirosis in Tehran and its suburban areas. Iranian Journal of Veterinary Resources, 5(2), 1383-1389.

22. Aslantaş Ö., Özdemir V., Kiliç S., and Babür, C. (2005). Seroepidemiology of leptospirosis, toxoplasmosis, and leishmaniosis among dogs in Ankara, Turkey. Veterinary parasitology, 129(3), 187-191.

23. Samir A., Soliman R., El-Hariri M., Abdel-Moein K., and Hatem, ME. (2015). Leptospirosis in animals and human contacts in Egypt: broad range surveillance. Revista da Sociedade Brasileira de Medicina Tropical, 48(3), 272-277. 


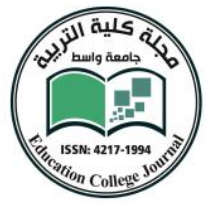

24. Stokes JE., Kaneene JB., Schall WD., Kruger JM., Miller R., Kaiser L., and Bolin, CA. (2007). Prevalence of serum antibodies against six Leptospira serovars in healthy dogs. Journal of the American Veterinary Medical Association, 230(11), 1657-1664.

25. Morikawa VM., Pellizzaro M., Kikuti M., and Molento, MB. (2015). Seroprevalence and seroincidence of Leptospira infection in dogs during a one-year period in an endemic urban area in Southern Brazil. Revista da Sociedade Brasileira de Medicina Tropical, 48(1), 50-55.

26. Barr SC., McDonough PL., and Starr, JK. (2005). Serologic responses of dogs given a commercial vaccine against Leptospira interrogans serovar pomona and Leptospira kirschneri. American journal of veterinary research, 66(10), 1780-1784.

27. Azócar-Aedo L., Smits HL., and Monti, G. (2014). Leptospirosis in dogs and cats: epidemiology, clinical disease, zoonotic implications and prevention. Arch Med Vet, 46, 337-348.

28. Schuller S., Francey T., Nally JE., and Sykes, J. (2015). European consensus statement on leptospirosis in dogs and cats. Journal of Small Animal Practice, 56(3), 159-179.

29. Pappas G., Papadimitriou P., and Akritidis, N. (2008). The globalization of leptospirosis: worldwide incidence trends. International Journal of Infectious Diseases, 12(4), 351-357.

30. Victoriano AF., Smythe LD., Cavinta LL., Kasai T., Limpakarnjanarat K., and Yanagihara, Y. (2009). Leptospirosis in the Asia Pacific region. BMC infectious diseases, 9(1), 147.

31. Hennebelle JH., and Foley, J. (2014). Risk factors associated with leptospirosis in dogs from Northern California: 2001-2010. Vector-Borne and Zoonotic Diseases, 14(10), 733-739.

32. Magwedere K., Hemberger MY., Hoffman LC., and Dziva, F. (2012). Zoonoses: a potential obstacle to the growing wildlife industry of Namibia. Infection ecology \& epidemiology, 2.

33. Sykes JE., Hartmann K., Lunn KF., Moore GE., Stoddard RA., and Goldstein RE. (2011). 2010 ACVIM small animal consensus statement on leptospirosis: diagnosis, epidemiology, treatment, and prevention. Journal of Veterinary Internal Medicine, 25(1), 1-13.

34. Gautam R., Guptill LF., Wu CC., Potter A., and Moore, GE. (2010). Spatial and spatio-temporal clustering of overall and serovar-specific Leptospira microscopic agglutination test (MAT) seropositivity among dogs in the United States from 2000 through 2007. Preventive veterinary medicine, 96(1), 122-131.

35. Langston CE., and Heuter, KJ. (2003). Leptospirosis: A re-emerging zoonotic disease. Veterinary Clinics of North America: Small Animal Practice, 33(4), 791-807. 
36. Ostfeld RS., and Holt, RD. (2004). Are predators good for your health? Evaluating evidence for top-down regulation of zoonotic disease reservoirs. Frontiers in Ecology and the Environment, 2(1), 13-20.

37. Lee HS., Guptill L., and Moore, GE. (2014). Signalment changes in canine leptospirosis between 1970 and 2009. Journal of veterinary internal medicine, 28(2), 294-299.

38. Sessions JK., and Greene, CE. (2004). Canine leptospirosis: epidemiology, pathogenesis, and diagnosis. Compendium on continuing education for the practicing veterinarian-North America edition, 26(8), 606-624.

39. Saleem MH., Khan MS., Khan MA., Khan MA., Ijaz M., Hassan A., and Mehmood, K. (2013). Serosurveillance of canine leptospirosis under different climatic conditions in and around Lahore, Pakistan. Pak Vet J, 33, 241-243.

40. White AM., Zambrana-Torrelio C., Allen T., Rostal MK., Wright AK., Ball EC., and Karesh, WB. (2017). Hotspots of canine leptospirosis in the United States of America. The Veterinary Journal, 222, 29-35.

41. Ghneim GS., Viers JH., Chomel BB., Kass PH., Descollonges DA., and Johnson, ML. (2007). Use of a case-control study and geographic information systems to determine environmental and demographic risk factors for canine leptospirosis. Veterinary research, 38(1), 37-50. 